\title{
Exploring Association Between Emotional Intelligence And Job Satisfaction Of Subject Specialists
}

\author{
Dr. Farah Deeba
}

Assistant professor, Department of Education, Bahauddin Zakariya University, Multan. farahgillani@bzu.edu.pk

\section{Amna Saleem}

Lecturer, Department of Education, The Women University, Multan. amna.6105@wum.edu.pk

\author{
Shabnam Noor \\ M.Phil. Scholar, Department of Education, Bahauddin Zakariya University, Multan
}

\section{ABSTRACT:}

The purpose of the present study was to explore the association between emotional intelligence and job satisfaction of subject specialists of public higher secondary schools of district Lahore. For this purpose, a five-point Likert type scale, an emotional intelligence scale, and a Job Satisfaction Scale was used to measure emotional intelligence and job satisfaction respectively. The demographic variables were gender, locality, subject, academic qualification, age, and teaching experience whose percentages were calculated. Each scale was split into four components of each variable and then percentage responses mean, standard deviation, skewness, and kurtosis were applied to study the statistics of these variables. The mean score of financial matters was the lowest and that of understanding was the highest. The zero value of skewness and kurtosis showed that the data was normal. Furthermore, an independent sample t-test was applied to find the comparison of two variables based on gender discipline, marital status, and locality. ANOVA was used to find out the comparison of more than two variables academic qualification, age, and teaching experience. Correlation between the two variables the Emotional Intelligence and Job Satisfaction was calculated by using Pearson's coefficient which showed that there was a positive significant strong correlation between these two variables. Further regression analysis was done to find the description of the effect. There was a significant effect of emotional intelligence on job satisfaction. Independent variable managing was the best predictor of job satisfaction.

Keywords:

Emotional Intelligence, Job Satisfaction, Pearson's Coefficient, Skewness, Kurtosis.

Article Received: 18 October 2020, Revised: 3 November 2020, Accepted: 24 December 2020

\section{INTRODUCTION:}

Human beings are made up of various emotions like anger, fear, and joy. Numerous psychologists take emotion as a combination of feelings, thinking, and experience which are often tangled with our

mood, temperament, personality, disposition, creat ivity, and motivation. A person's emotions are directly related to their mental processes or intelligence also and when we control, manage and regulate our emotions intelligently, it is characterized as Emotional Intelligence. Emotional intelligence is usually revealed in everchanging desires, confronting obstacles, respectful treatment towards others, and the formation and maintenance of effective interpersonal relationships. In other words, emotional intelligence determines how we treat ourselves (Aykan, 2014).

In this way, Emotional Intelligence is the sum of all traits and abilities that guide individual emotional practices by playing a multifunctional role of interconnected emotional, personal, and social abilities that ultimately stimulate a person to outperform by using all his abilities. In this way, he can handle demands and pressures in his workplace effectively and efficiently Bar-On \& Parker (2000). Emotional intelligence is to 
understand the abilities and qualities of individuals that are related to their emotions (Emmerling \& Goleman, 2003). It is the capability to understand one's own emotions and those of others (Biswas, 2016).

Emotional Intelligence is an important and interesting concept introduced to psychology, management, and education in the last decade (Shooshtarian, 2013). In the educational context, Salim et al (2012) stated that a teacher can have the best training, a critical mind, an endless amount of ideas but cannot become a great teacher without emotional intelligence. It may be supposed that emotional intelligence is very significant in ensuring teachers' effectiveness in controlling the emotions of students and colleagues because the teaching profession involves teaching, cultivating, and leading the students. Therefore, El-Badawy and Magdy (2015) take emotional intelligence as a key factor for the success of teachers.

Subsequently, the result proved that the teacher's performance is best seen if he is capable, understands social setup, and then can regulate his emotions. Besides, to increase competition in almost all sectors especially in teaching, the analysis of emotional intelligence ability and Job satisfaction of teachers has been one of the most critical research subjects to get the highest outcomes from teachers (Orhan\& Dincer, 2012). Emotional intelligence is believed to enhance social responsibility, problem-solving capacity, stress tolerance, impulse control, and happiness of teachers (Afolabi, Ogunmwonyi \& Okediji,2009).

The objective of emotional intelligence is to facilitate the individual in developing selfknowledge in the world of emotions to guide them to reach their destination. Teachers with a higher level of emotional intelligence are more effective to make their organization more successful and fruitful. Teachers with advanced emotional intelligence possess the ability to exhibit selfcontrol over their emotions, perceive the emotional state of others, and utilize this information effectively while dealing with others (Mayer and Geher, 1996).

The study results by Kportufe (2014) suggested that government and policymakers might play an important role as both facilitators for educators in encouraging educational institutions to train teachers to be emotionally intelligent. However, emotional intelligence is not only sufficient for the good performance of teachers as some other factors also influence it like teachers motivation, self-efficacy, selfesteem, and even their high satisfaction level for their job at their workplace.

Feeling about own job is called job satisfaction, it means how the person likes or dislikes his job (Biswas, 2016). Job satisfaction is the feeling of fulfillment or enjoyment that a person develops from his job at his workplace. Moreover, in other words, job satisfaction is a positive feeling toward one's job. If a person has positive thinking about his job, he will be more satisfied with his work, if he has negative thinking he will be dissatisfied with his job. Thus in a positive mental condition, the person becomes more committed to his job and gives the best results and outcomes. Next, one of the indicators of high job satisfaction is the quality of the work. Finally, job satisfaction cannot only influence work output but also affects work effort, the quality of the working circumstance, staff turnover and retention, compensation level, fairness in the promotion system within an institution, and many more. Also, job satisfaction is an important element in the teaching profession as well as for the teacher. If teachers are not satisfied with their profession then it is very difficult for them to perform their job honestly, devotedly, and competently. Moreover, the different attitude of teachers determines their job satisfaction. These attitudes are related to different elements which can be described as salary, service infrastructure, and other opportunities.

Hayat Bibi \& Ambreen, (2016) described these conditions which may elevate emotional 
intelligence and ultimately job satisfaction of teachers like his passion to work if his heart is not in his work, he has a job but he has no passion for it. Passion alone is not sufficient. The teacher has to be good at what he does. Being good enough will not give him the satisfaction he wants. The teacher has to excel at his work and be remarkable. Mastery is the aim and the teacher wants to have such a product that has a good market value in the form of his students. If his students are on a successful career, his job is profitable and satisfied. Job satisfaction is a worker's sense of achievement and success on the job. It is generally perceived to be directly linked to productivity as well as to personal well-being. Job satisfaction implies doing a job one enjoys, doing it well, and being rewarded for one's efforts. Job satisfaction further implies enthusiasm and happiness with one's work. Job satisfaction is the key ingredient that leads to recognition, income, promotion, and the achievement of other goals that lead to a feeling of fulfillment (Kaliski, 2007). Job satisfaction is the extent to which a worker is contented with the rewards he or she gets out of his or her job, particularly in terms of intrinsic motivation (Statt, 2004). The term job satisfaction refers to the attitude and feelings people have about their work. Positive and favorable attitudes towards the job indicate job satisfaction. Negative and unfavorable attitudes towards the job indicate job dissatisfaction (Armstrong, 2006).

Job satisfaction is the collection of feelings and beliefs that people have about their current job. People's levels of degrees of job satisfaction can range from extreme satisfaction to extreme dissatisfaction. In addition to having attitudes about their jobs as a whole. People also can have attitudes about various aspects of their jobs such as the kind of work they do, their coworkers, supervisors, or subordinates, and their pay (George, 2014).

Job satisfaction is a complex and multifaceted concept that can mean different things to different people. Job satisfaction is usually linked with motivation, but the nature of this relationship is not clear. Satisfaction is not the same as motivation. Job satisfaction is more of an attitude, an internal state. It could, for example, be associated with a personal feeling of achievement, either quantitative or qualitative (Mullins, 2007). We consider that job satisfaction represents a feeling that appears as a result of the perception that the job enables the material and psychological needs (Aziri, 2011). While analyzing job satisfaction the logic is that a satisfied employee is a happy employee and a happy employee is a successful employee.

Emotional intelligence and job satisfaction are two modern concepts in research and are of great interest because nowadays teacher is facing problems of over workload and students attitude to handle job complications, a teacher has to attain such capabilities like emotional intelligence and job satisfaction simultaneously (Biswas, 2016).

Researchers found that emotional intelligence is a predictor of job satisfaction of SSTs in Nigeria. It is suggested that a teacher should be equipped with the necessary stress management skills (Akomolafe \& Ogunmakin, 2014). Also, a significant relationship was found between the use of emotion, regulation of emotion with Job satisfaction of university lecturers in Kano State Kassim,Bambale \& Jakada (2016) Similarly, a positive relationship was shown between emotional intelligence and job satisfaction and no effect of gender is noted in the relationship between emotional intelligence and job satisfaction of Malaysian primary and secondary school teachers (Salim et al;2012). In the same way, the Result of Biswas (2016) study showed that emotional intelligence and Job satisfaction of Indian teachers are strongly linked.

Furthermore, emotional intelligence was associated with years of teaching experience and Job satisfaction. Emotional intelligence can be measured by self-reports which were made by different psychologists at different times (Cobb, 2004). Also, the interaction between two variables i.e. emotional intelligence and physiological stress 
significantly correlated with job satisfaction in private sector higher-level schools.

A significant positive correlation was found between employee's emotional competency and Job satisfaction in Kayseri (Aykan \& Aksoylu, 2015). Moreover, the study revealed the emotional intelligence of principals had a significant positive correlation with the job satisfaction of teachers in Sri Lanka (Kappagoda, 2011).

The results of the research reported a positive relationship between job satisfaction and emotional intelligence with leadership style. Next, it can be said that a successful leadership style is an effective factor in the job satisfaction of teachers and high emotional intelligence can make an effective leadership style in teachers that can improve job satisfaction by using this kind of leadership style (Aftab, 2015). In brief, positive correlations were found between teachers' emotional intelligence and job satisfaction (Fakiruddin, 2011). Moreover, SSTs' emotional intelligence was correlated with job satisfaction in Malaysia (Yoke \& Panatik, 2015). Similarly, the results of the study revealed that there was a positive and significant correlation between two variables emotional intelligence and job satisfaction of EFL teachers in Iran/Shiraz (Hekmatzadeh, Khojasteh, \& Shokrpour, 2016). Results of a study by Siddique et al. (2014) demonstrated a significant association between two variables, emotional intelligence and job satisfaction of teachers of Pakistani higher education institutions.

Emotional intelligence and job satisfaction are important in all fields and professions of life such as medicine, agriculture, the banking sector, and education. Researchers did a lot of work on emotional intelligence and job satisfaction in various professions in the world. Also, the job satisfaction of teachers is very important and effective in the teaching profession. Thus, effective teaching is the result of job satisfaction. Therefore, teachers must be emotionally intelligent to overcome the problems of teaching.
Training centers should be developed (Biswas, 2016).

Furthermore, teachers deal with students, parents, colleagues, and heads of institutions in their daily routine. The teacher is a source of bringing change and also a source to increase the economy. In brief, emotional intelligence helps assist teachers to communicate with others effectively. Thus, there is a desire need to find out the correlation between the two variables emotional intelligence and job satisfaction of subject specialists. In short, teachers are changing agent in the society

Developing countries like Pakistan are rich in emotional sentiments due to the strong cultural influence of experience on future outcomes. This study is an attempt to find the relationship between emotional intelligence and job satisfaction. The effective handling of emotions particularly at the workplace is an indicator of job satisfaction, therefore, causes immense outcomes that eventually increase productivity are the source of increasing the economy. Furthermore, teachers deal with students, parents, colleagues, and heads of institutions in their daily routine. In brief, emotional intelligence helps assist teachers to communicate with others effectively.

It is evident from the above-mentioned literature that emotional intelligence and its association with the job satisfaction of teachers is an evolving topic for researchers in recent years because there studies on emotional intelligence and especially on the relationship between emotional intelligence and job satisfaction are neglected from the Pakistani perspective. Therefore, researchers thought it appropriate to highlight such research that focuses on emotional intelligence and job satisfaction of teachers.

\section{STATEMENT OF THE PROBLEM:}

The present research was an effort to study the relationship between emotional intelligence and job satisfaction of subject specialists at the secondary level. Teachers are a very important component of any education system. They serve as the foundation of a nation. Furthermore, 
trained, capable and knowledgeable teachers provide excellent learning. Teaching is a highly noble profession and teachers always give benefit to the society in its growth and development. One of the aims of education is meaningful interaction between the teacher and learner. The teacher plays a key role in student molding into a responsible citizen, while his Job satisfaction affects his emotions and his control over emotions and their management shows his intelligence which is very important in the field of education and interaction with students. So, there is a need to investigate the relationship between emotional intelligence and job satisfaction.

\section{OBJECTIVES OF THE STUDY:}

The Objectives of this study were:
- To find out the relationship between emotional intelligence and job satisfaction of subject specialist teachers.

- To find the effect of emotional intelligence on job satisfaction of subject specialists.

- To compare emotional intelligence and job satisfaction of subject specialists from diverse perspectives (gender locality, subject, academic qualification, marital status, age and teaching experience).

\section{CONCEPTUAL FRAMEWORK OF THE}

\section{STUDY:}

Orodho (2014). defines a conceptual framework as a way of representing the relationship between the variables diagrammatically. The conceptual framework of the present research is as depicted in the diagram.

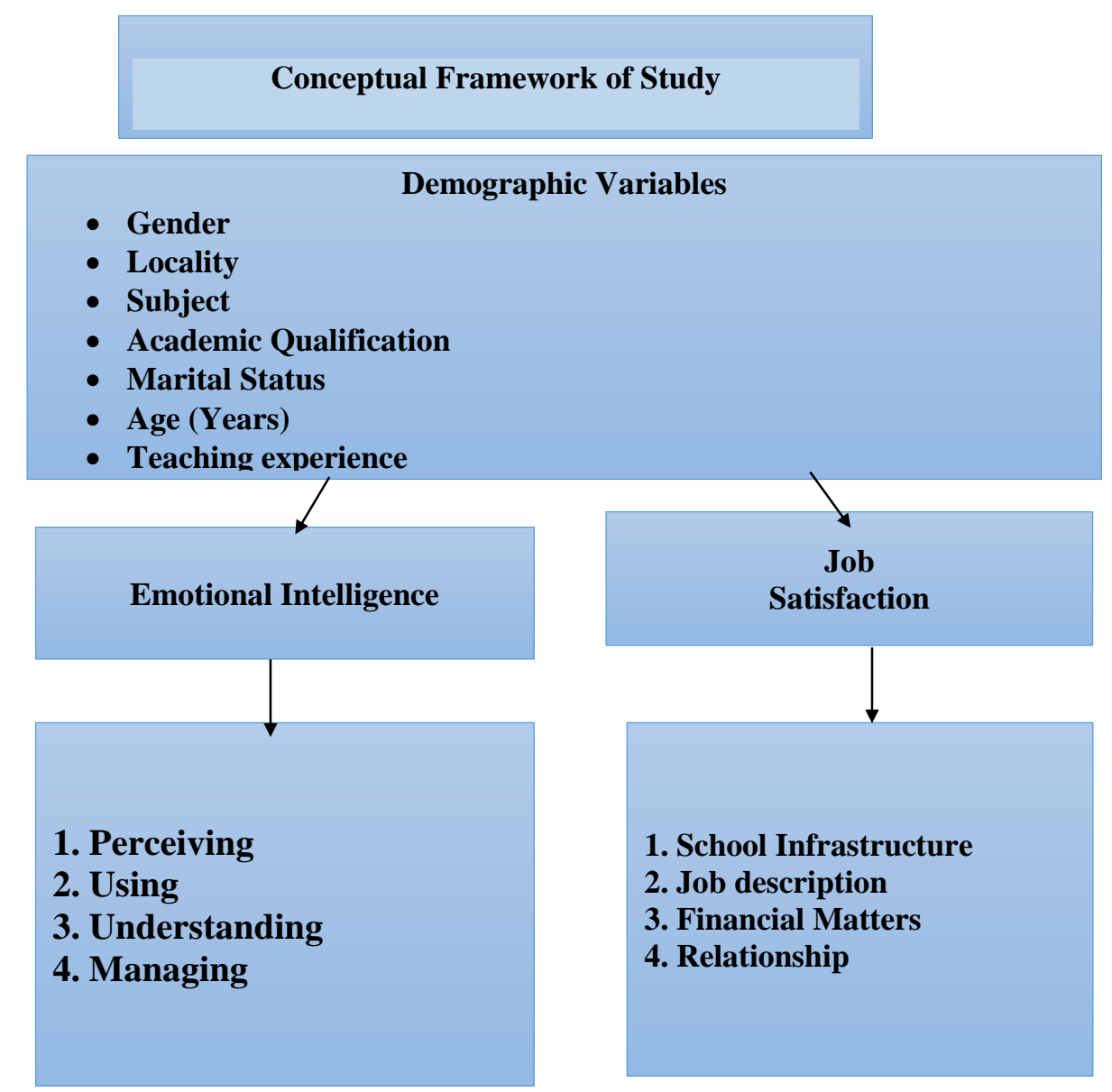

Fig no 01: Framework of the study 
The present study was correlational and Pearson's coefficient was calculated to find a correlation between emotional intelligence and job satisfaction

\section{Research Design:}

In the present study, the correlational and quantitative design was used. Because to Gay \& Salaman (1992) "the collection of numerical data to explain and predict the phenomena is quantitative research. "Further Gay (1996) explains correlational research as "correlational research collects data to determine whether and to what degree, a relationship exists between two or more quantifiable variables."

\section{Population and Sample:}

This study was conducted in public higher secondary schools in Lahore, Pakistan. The population of the study included subject specialist teachers in public higher secondary schools. Only district Lahore was chosen to collect the data as convenient sampling and all 25 schools of male and female were taken from all five tehsils of district Lahore. The data was collected from 65 male and 206 female subject specialists from all schools. However, data received from 250 teachers as the remaining were on study leave, maternity leave, and Ex-Pakistan leave. In this way, the total number of respondents of the study was 250 .

Table no 01: Demographic information of the participants

\begin{tabular}{|c|c|c|c|}
\hline Variables & Levels & Frequency & Percentage \\
\hline \multicolumn{4}{|l|}{ Gender } \\
\hline & Male & 56 & 22 \\
\hline & Female & 194 & 78 \\
\hline \multicolumn{4}{|l|}{ Local } \\
\hline & Urban & 179 & 72 \\
\hline & Rural & 71 & 28 \\
\hline \multicolumn{4}{|l|}{ Subject } \\
\hline & Arts SS & 124 & 49 \\
\hline & Science SS & 126 & 51 \\
\hline \multicolumn{4}{|c|}{ Academic Qualification } \\
\hline & MA & 59 & 24 \\
\hline & MSc & 121 & 48 \\
\hline & M.Phil. & 61 & 24 \\
\hline & Ph.D. & 9 & 4 \\
\hline \multirow[t]{2}{*}{ Marital Status } & Unmarried & 122 & 52 \\
\hline & Married & 121 & 48 \\
\hline \multirow[t]{4}{*}{ Age (years) } & $\leq 30$ & 71 & 28 \\
\hline & 31 to 40 & 81 & 32 \\
\hline & 41 to 50 & 47 & 19 \\
\hline & $<50$ & 51 & 20 \\
\hline \multicolumn{4}{|c|}{ Teaching experience } \\
\hline & $<10$ & 147 & 59 \\
\hline & $10-20$ & 39 & 16 \\
\hline & $>30$ & 64 & 26 \\
\hline
\end{tabular}


Table no 01 shows the information about the demographic variables. The sample size of the research was $\mathrm{N}=250$. Fifty-six $(22 \%)$ of the sample belongs to the male gender and $194(78 \%)$ of the sample are female. Also, $179(71.6 \%)$ of them belong to urban areas while $71(28.4 \%)$ of them belong to rural areas. In sample 124 (49\%) of them were arts subject specialists Urdu medium and $126(51 \%)$ of them are science subject specialist. Furthermore, there are $59(23.6 \%)$ individuals who have done Masters, 121 (48.4\%) have done MSc, 61 (24.4\%) of them have done M.Phil. and $9(3.6 \%)$ have done Ph.D. Also teaching experience $147(59 \%)$ of them are greater than ten years, 39(16\%) of them are between 10 and 20years while $64(26 \%)$ of them are greater than 30 years. In the same way, $122(52 \%)$ subject specialists were unmarried 121 (48\%) were married.

\section{Research Instruments:}

In this present study, two instruments were used to measure emotional intelligence and job satisfaction separately. The emotional intelligence measurement scale was a self-report measure having 30 items. Schutte et al (1998) self-report emotional intelligence test (SSEIT) was used as the model which was further modified keeping in view the Pakistani context and education system in higher secondary schools. The job satisfaction scale having 16 items was a self-developed test. However, it was set after an extensive review of literature about the scale of the job. Both instruments were divided into four factors having five options. The emotional intelligence scale was divided into four factors;

1. Perceiving

2. Using

3. Understanding

4. Managing

Likewise, the job satisfaction scale was also divided into four factors;

1. School infrastructure

2. Job description

3. Financial matters

\section{Relationship}

\section{Validity and Reliability of Instruments:}

The validity of the instrument reflects the extent to which the instrument measures what it was supposed to measure. It is the quality of the instrument. Five experts who fulfilled the criteria mentioned below were selected from the Institute of Education and Research Lahore, Pakistan to judge the validity of the instrument:

- Experts having experience in the field of education.

- Experts having experience in the field of scale development.

- Experts having experience in the field of Educational Psychology.

Experts' suggestions were related to items' language, arrangement, no of items, and presentations of sub-scales. It was found valid as it measured what it was supposed to measure.

The Cronbach alpha was 0.832 for the emotional intelligence scale and 0.870 for job satisfaction which shows good reliability of both scales.

\section{Statistical Data Analysis:}

The present study was correlational; the correlation between the two variables emotional intelligence and job satisfaction was calculated. For this Pearson's Product Moment Correlation was applied as inferential analysis by using SPSS version 20.

The demographic variables were included gender, Local, Subject, Academic qualification, Age, and Teaching experience whose percentages were calculated. Each questionnaire was split into four categories and then percentage responses mean, standard deviation, skewness, and kurtosis were applied to study the statistics of these variables. The mean score of financial matters was the lowest and that of understanding was the highest. The zero value of skewness and kurtosis showed that the data was normal. Furthermore, an independent sample to test was applied to find the comparison of two variables male, female, arts 
and science, married, unmarried, and rural-urban Subject Specialists. ANOVA was used to find out the comparison of more than two variables such as academic qualification, age, and teaching experience. Correlation between the two variables the emotional intelligence and job satisfaction was calculated by Pearson's coefficient which showed that there was a positive significant strong correlation between these two variables. Further regression analysis was done to find the description of the effects. There was a significant effect of emotional intelligence on job satisfaction. Independent variable managing was the best predictor of job satisfaction.

RESULTS:

Table no 02: Pearson's correlation between Emotional Intelligence and Job Satisfaction

\begin{tabular}{|c|c|c|c|c|c|c|c|c|c|c|}
\hline & 1 & 2 & 3 & 4 & 5 & 6 & 7 & 8 & 9 & 10 \\
\hline $\begin{array}{l}\text { 1.Emotional } \\
\text { intelligence }\end{array}$ & & $.864 * *$ & $.755^{* *}$ & $.795^{* *}$ & $.761 * *$ & $.535 * *$ & $.410 * *$ & .107 & $.483 * *$ & $.544 * *$ \\
\hline 2.Perceiving & & & $.506^{* *}$ & $.571 * *$ & $.546 * *$ & $.441 * *$ & $.337 * *$ & .095 & $.396 * *$ & $.447 * *$ \\
\hline 3.Using & & & & $.614 * *$ & $.393 * *$ & $.370 * *$ & $.316^{* *}$ & .041 & $.292 * *$ & $.426 * *$ \\
\hline 4.Understanding & & & & & $.450 * *$ & $.430 * *$ & $.346^{* *}$ & .058 & $.376^{* *}$ & $.468 * *$ \\
\hline 5.Managing & & & & & & $.461 * *$ & $.312 * *$ & $.134 *$ & $.463 * *$ & $.404 * *$ \\
\hline 6.Job satisfaction & & & & & & & $.784 * *$ & $.543 * *$ & $.912 * *$ & $.821 * *$ \\
\hline $\begin{array}{l}\text { 7.School } \\
\text { infrastructure }\end{array}$ & & & & & & & & $.306 * *$ & $.630 * *$ & $.542 * *$ \\
\hline 8.Financial matters & & & & & & & & & $.409 * *$ & $.197 * *$ \\
\hline 9.Job description & & & & & & & & & & $.679 * *$ \\
\hline 10.Relationship & & & & & & & & & & - \\
\hline
\end{tabular}

Table no 02 shows Pearson's correlation between emotional intelligence and job satisfaction. There was a positive significant strong relationship between Emotional intelligence and Job satisfaction $(\mathrm{r}=.535, \mathrm{p}<.01)$. $)$. There was a positive significant medium relationship between emotional intelligence and School Infrastructure $(\mathrm{r}=.410, \quad \mathrm{p}<.01)$. There was no significant relationship between emotional intelligence and Financial matters $(r=.107, p<.01)$. $)$. There was a positive significant medium relationship between emotional intelligence and job description $(\mathrm{r}=.483, \mathrm{p}<.01)$. There was a positive significant strong relationship between emotional intelligence and job satisfaction factor relationship $(\mathrm{r}=.544$, $\mathrm{p}<.01)$.

Table no 03: Summary of Regression Analysis: Effect of emotional intelligence on job satisfaction

\begin{tabular}{llllllll}
\hline Job satisfaction & $\mathrm{B}$ & $\mathrm{SE}$ & $\mathrm{B}$ & $\mathrm{t}$ & $\mathrm{p}$ & Tolerance & VIF \\
Constant & 1.39 & 0.24 & & 5.68 & $<.001$ & & \\
Perceiving & 0.18 & 0.09 & 0.16 & 2.16 & .032 & 0.55 & 1.83 \\
Using & 0.07 & 0.06 & 0.08 & 1.15 & .251 & 0.58 & 1.72 \\
Understanding & 0.14 & 0.06 & 0.17 & 2.29 & .023 & 0.52 & 1.92 \\
Managing & 0.24 & 0.06 & 0.27 & 4.08 & $<.001$ & 0.67 & 1.49 \\
\hline $\mathrm{R}^{2}=30$ & & & & & & &
\end{tabular}


Multiple regression was conducted to find the effect of emotional intelligence on job satisfaction. All independent variables 30\% explained variance in job satisfaction. There was a significant effect of emotional intelligence on job satisfaction $F(4,452)=25.66, \quad \mathrm{p}<.001$.
Independent variable managing was the best predictor of job satisfaction $(\beta=.27, \mathrm{p}<.001)$ while understanding $(\beta=.17, \mathrm{p}<.023)$ and Perceiving $(\beta=.16, p<.032)$ were $2^{\text {nd }}$ and $3^{\text {rd }}$ best predictors respectively.

Table no 04: Summary Statistics of Study Variables

\begin{tabular}{|c|c|c|c|c|c|c|}
\hline & Min. & Max. & Mean & $S D$ & skewness & Kurtosis \\
\hline Emotional intelligent & 2.40 & 4.50 & 3.68 & 0.42 & -0.748 & 0.328 \\
\hline Perceiving & 2.33 & 4.50 & 3.55 & 0.44 & -0.469 & 0.287 \\
\hline Using & 1.83 & 5.00 & 3.77 & 0.56 & -0.537 & 0.341 \\
\hline Understanding & 1.60 & 5.00 & 3.93 & 0.64 & -0.905 & 0.732 \\
\hline Managing & 1.71 & 4.86 & 3.63 & 0.58 & -0.676 & 0.391 \\
\hline Job satisfaction & 2.26 & 4.95 & 3.70 & 0.51 & -0.407 & -0.276 \\
\hline School infrastructure & 1.00 & 5.00 & 3.71 & 0.64 & -0.995 & 1.611 \\
\hline Financial matters & 1.00 & 5.00 & 3.36 & 1.01 & -0.553 & -0.153 \\
\hline Job description & 2.00 & 4.86 & 3.68 & 0.57 & -0.583 & -0.066 \\
\hline Relationship & 1.80 & 5.00 & 3.84 & 0.61 & -0.712 & 0.342 \\
\hline
\end{tabular}

Table no 04 shows the Summary Statistics of Study Variables: Emotional intelligence and its factors, Job satisfaction and its factors. The emotional intelligent construct is composed of four factors; Perceiving, Using, Understanding, and managing while Job satisfaction constructs also compose of four factors; School infrastructure, Financial matters, Job description, and Relationship. The summary statistics explain five characteristics of each variable 1. Minimum value, Maximum value, Mean, Standard deviation, skewness, and kurtosis of the variable. Minimum and maximum value helps to determine the potential range of the study data. Some variables have a wide range like School infrastructure, financial matters, and some variable narrow range like emotional intelligence, Perceiving, and Job description. The mean score explains the gravity of the variable. The mean scores of Financial matters are lowest (Mean=3.36) and the mean scores of Understanding are highest (Mean=3.93). The skewness and kurtosis is an indicator of normality. The zero value of skewness and kurtosis shows perfect normality. The value of skewness and kurtosis indicates that data is approximately normal and parametric statistics can be used for these variables.

Table no 05: Comparison of male and female SS on Emotional Intelligence and Job Satisfaction

\begin{tabular}{llllllll}
\hline & Male & \multicolumn{3}{c}{ Female } & \multicolumn{3}{c}{ Independent samples t-test } \\
\hline Scales & $M$ & $S D$ & $M$ & $S D$ & $\mathrm{~T}$ & $\mathrm{df}$ & $\mathrm{P}$ \\
Emotional intelligent & 3.41 & 0.43 & 3.75 & 0.39 & -5.68 & 248 & $<.001$ \\
Perceiving & 3.37 & 0.45 & 3.60 & 0.42 & -3.56 & 248 & $<.001$ \\
Using & 3.46 & 0.53 & 3.86 & 0.54 & -4.86 & 248 & $<.001$ \\
Understanding & 3.41 & 0.63 & 4.08 & 0.57 & -7.53 & 248 & $<.001$ \\
Managing & 3.43 & 0.56 & 3.69 & 0.57 & -3.069 & 248 & 0.002 \\
Job satisfaction & 3.38 & 0.42 & 3.79 & 0.50 & -5.59 & 248 & $<.001$ \\
School infrastructure & 3.39 & 0.61 & 3.80 & 0.62 & -4.37 & 248 & $<.001$ \\
\hline
\end{tabular}




\begin{tabular}{llllllll}
\hline Financial matters & 3.13 & 0.86 & 3.43 & 1.04 & -1.92 & 248 & 0.056 \\
Job description & 3.37 & 0.54 & 3.77 & 0.55 & -4.81 & 248 & $<.001$ \\
Relationship & 3.46 & 0.60 & 3.95 & 0.57 & -5.56 & 248 & $<.001$ \\
\hline
\end{tabular}

Table no 05 shows the data about emotional intelligence. Participants further were divided into two groups according to their gender. A significant difference was found in emotional intelligence between male and female SS $(\mathrm{t}=-5.68$, $\mathrm{p}<0.001)$. In the same way the a significant difference in perceiving between male and female SS $(\mathrm{t}=-3.56, \mathrm{p}<0.001) . \quad$ The Female $(\mathrm{M}=3.75$, $\mathrm{SD}=0.39)$ participants were more perceiving a male $(\mathrm{M}=3.41$. $\mathrm{SD}=0.43)$ participants). In the same found significant difference of using between male and female SS $(\mathrm{t}=-4.86, \mathrm{p}=<0.001)$. Female $(\mathrm{M}=3.60, \mathrm{SD}=0.42)$ participants were more using then male $(\mathrm{M}=3.37, \quad \mathrm{SD}=0.45)$ participants. In the same way the a significant difference in understanding between male and female subject specialists $(\mathrm{t}=-7.53, \mathrm{p}<0.001)$. The female $(\mathrm{M}=3.86, \mathrm{SD}=0.54)$ participants were more understanding than the male $(\mathrm{M}=3.46$, $\mathrm{SD}=0.53$ ). And the significant difference of Managing between male and female subject specialists $\quad(\mathrm{t}=-3.069, \mathrm{p}<0.001)$. The female $(\mathrm{M}=7.24, \quad \mathrm{SD}=0.51)$ participants were more Managing than male $(\mathrm{M}=6.94, \mathrm{SD}=0.52)$ In the same way the a significant difference in job satisfaction between male and female subject specialists $(\mathrm{t}=-5.59, \mathrm{p}<0.001)$. Female participants $(\mathrm{M}=3.79, \mathrm{SD}=0.500)$ were more satisfied with their job than male ( $\mathrm{M}=3.38, \quad \mathrm{SD}=0.42)$ participants. It has also been observed that there was a significant difference in school infrastructure $\quad(\mathrm{t}=-4.37, \quad \mathrm{p}<0.001) . \quad$ Female $(\mathrm{M}=3.80, \quad \mathrm{SD}=0.62)$ participants were more satisfied with School infrastructure than male $(\mathrm{M}=3.39 . \mathrm{SD}=0.61)$ participants. $)$ and there was found no significant difference between male and female subject specialists $(\mathrm{t}=-3.069, \mathrm{p}=<0.001)$. It has also been observed that there was a significant difference in the job description $(\mathrm{t}=-4.81$, $\mathrm{p}$ $<0.001)$. The female $(\mathrm{M}=3.77, \quad \mathrm{SD}=0.55)$ participants were more satisfied with the job description than male ( $\mathrm{M}=3.37, \mathrm{SD}=0.53)$ and). And the significant difference in the relationship between male and female subject specialists $(\mathrm{t}=-$ $5.56, \mathrm{p}=<0.001)$. The female $(\mathrm{M}=3.95, \mathrm{SD}=0.57)$ participants were more satisfied with the relationship than the male $(\mathrm{M}=3.46, \mathrm{SD}=0.60)$. There was no significant difference between male and female subject specialists on financial matters.

Table no 06: Comparison of Urban and Rural on Emotional Intelligence and Job satisfaction

\begin{tabular}{llllllll}
\hline & Urban & & \multicolumn{3}{l}{ Rural } & \multicolumn{3}{l}{ Independent samples t-test } \\
\hline & $M$ & $S D$ & $M$ & $S D$ & T & df & P \\
Emotional intelligence & 3.67 & 0.41 & 3.69 & 0.46 & -0.27 & 248 & 0.789 \\
Perceiving & 3.55 & 0.43 & 3.54 & 0.46 & 0.12 & 248 & 0.905 \\
\hline Using & 3.77 & 0.56 & 3.79 & 0.59 & -0.31 & 248 & 0.755 \\
Understanding & 3.89 & 0.65 & 4.04 & 0.63 & -1.74 & 248 & 0.084 \\
Managing & 3.65 & 0.56 & 3.59 & 0.62 & 0.64 & 248 & 0.521 \\
Job satisfaction & 3.72 & 0.53 & 3.65 & 0.47 & 1.02 & 248 & 0.308 \\
School infrastructure & 3.70 & 0.66 & 3.72 & 0.58 & -0.21 & 248 & 0.836 \\
Financial matters & 3.44 & 0.99 & 3.15 & 1.02 & 2.11 & 248 & $0.036^{*}$ \\
\hline Job description & 3.72 & 0.56 & 3.58 & 0.58 & 1.72 & 248 & 0.086 \\
\hline Relationship & 3.84 & 0.63 & 3.86 & 0.58 & -0.30 & 248 & 0.761 \\
\hline
\end{tabular}

$* \mathrm{p}<.05$ 
Independent samples t-test was conducted to compare Urban and Rural subject specialist on emotional intelligence and its factors, job satisfaction and its factors. There was no significant difference between urban and rural subject specialists on emotional intelligence $(\mathrm{t}=-$ 0.27, $\mathrm{p}=0.0789$ ). There was no significant difference between urban and rural subject specialists on Understanding $(\mathrm{t}=0-1.74, \mathrm{p}=0.084)$. The mean score of rural $(M=4.04, S D=0.63)$ was similar to urban subject specialists $(M=3,89$, $S D=0.65$ ). There was no significant difference between urban and rural subject specialists on job satisfaction $(\mathrm{t}=1.02, \mathrm{p}=0.308)$. The mean score of urban subject specialists $(M=3.72, S D=0.53)$ was similar to rural subject specialists $(M=3.65$, $S D=0.47)$. There was no significant difference between urban and rural subject specialists on
Financial matters $(\mathrm{t}=-2.11, \mathrm{p}=0.036)$. The mean score of urban $(M=3.44, S D=0.99)$ was similar to rural subject specialists $(M=3.15, S D=1.02)$. There was observed no significant difference of urban and rural subject specialists on Job description $(\mathrm{t}=1.72, \mathrm{p}=0.086)$. The mean score of urban subject specialists $(\mathrm{M}=3.72, \mathrm{SD}=0.56)$ was similar to rural subject specialists mean score $(\mathrm{M}=3.58, \mathrm{SD}=0.58)$. There was no significant difference between urban and rural subject specialists on Emotional Intelligence Perceiving, Using, Managing, School Infrastructure and Relationship ( $p>.05$ ). A significant difference was found only on Financial matters $(t=2.11, p=0.036)$ of urban and rural subject specialists. The mean score of urban subject specialists $(M=3.44$, $S D=0.99)$ was more than rural subject specialists $(\mathrm{M}=3.15, \mathrm{SD}=1.02)$.

Table no 07: Comparison of Arts and SS on Emotional Intelligence and Job Satisfaction

\begin{tabular}{|c|c|c|c|c|c|c|c|}
\hline & \multicolumn{2}{|c|}{ Arts SS } & \multicolumn{2}{|c|}{ Science SS } & \multicolumn{3}{|c|}{$\begin{array}{l}\text { Independent samples } \\
\text { t-test }\end{array}$} \\
\hline & $M$ & $S D$ & $M$ & $S D$ & $\mathrm{t}$ & df & $\mathrm{P}$ \\
\hline $\begin{array}{l}\text { Emotional } \\
\text { intelligence }\end{array}$ & 3.61 & 0.38 & 3.75 & 0.46 & -2.66 & 248 & 0.008 \\
\hline Perceiving & 3.49 & 0.40 & 3.61 & 0.46 & -2.18 & 248 & 0.030 \\
\hline Using & 3.65 & 0.54 & 3.89 & 0.56 & -3.41 & 248 & 0.001 \\
\hline Understanding & 3.85 & 0.61 & 4.01 & 0.67 & -1.89 & 248 & 0.060 \\
\hline Managing & 3.59 & 0.55 & 3.67 & 0.60 & -1.18 & 248 & 0.240 \\
\hline Job satisfaction & 3.65 & 0.48 & 3.75 & 0.54 & -1.55 & 248 & 0.122 \\
\hline $\begin{array}{l}\text { School } \\
\text { infrastructure }\end{array}$ & 3.66 & 0.64 & 3.75 & 0.64 & -1.22 & 248 & 0.222 \\
\hline $\begin{array}{l}\text { Financial } \\
\text { matters }\end{array}$ & 3.26 & 1.00 & 3.46 & 1.00 & -1.53 & 248 & 0.127 \\
\hline Job description & 3.62 & 0.55 & 3.74 & 0.59 & -1.72 & 248 & 0.086 \\
\hline Relationship & 3.83 & 0.61 & 3.86 & 0.62 & -0.44 & 248 & 0.657 \\
\hline
\end{tabular}

Table no 07 shows the information about Emotional Intelligence. Participants further were divided into two groups according to their subject. There was found a significant difference in emotional intelligence between arts and science subject specialist $\mathrm{t}=-2.66, \mathrm{p}=0.008)$. The respondents of the science group $(\mathrm{M}=3.75$, $\mathrm{SD}=0.46$ ) were more emotionally intelligent than arts group respondents $(\mathrm{M}=3.61 . \quad \mathrm{SD}=0.38)$ participants. There was a significant difference in perceiving between arts and science subject specialists $(\mathrm{t}=-2.18, \mathrm{p}=0.030)$. Also, science group participants $(\mathrm{M}=3.61, \mathrm{SD}=0.46)$ participants were more perceiving than arts group participants $(\mathrm{M}=3.49, \mathrm{SD}=0.40)$ participants. A significant difference was observed in Using between arts 
and science subject specialists $(\mathrm{t}=-2.18, \mathrm{p}=0.001)$. Furthermore, science group respondents $(\mathrm{M}=3.89 ., \mathrm{SD}=0.56)$ participants were more using than arts group participants $(\mathrm{M}=3.65, \mathrm{SD}=0.54)$.
There was no significant difference between the arts and science group on understanding, managing, job satisfaction, and its factors.

Table no 08: Comparison of SS of different Teaching Experience on Emotional Intelligence and Job Satisfaction

\begin{tabular}{lllllllll}
\hline & \multicolumn{7}{c}{ Teaching Experience (years) } \\
& $<10$ & & $11-20$ & $>20$ & & \multicolumn{2}{l}{ ANOVA } \\
& $M$ & $S D$ & $M$ & $S D$ & $M$ & $S D$ & F & P \\
Emotional intelligence & 3.69 & 0.40 & 3.73 & 0.39 & 3.61 & 0.48 & 1.15 & 0.319 \\
Perceiving & 3.57 & 0.38 & 3.54 & 0.45 & 3.51 & 0.54 & 0.37 & 0.693 \\
Using & 3.82 & 0.59 & 3.72 & 0.56 & 3.71 & 0.52 & 1.10 & 0.336 \\
Understanding & 3.91 & 0.67 & 4.10 & 0.57 & 3.87 & 0.60 & 1.65 & 0.195 \\
Managing & 3.64 & 0.56 & 3.79 & 0.52 & 3.52 & 0.64 & 2.86 & 0.059 \\
Job satisfaction & 3.66 & 0.55 & 3.86 & 0.44 & 3.70 & 0.44 & 2.31 & 0.101 \\
School infrastructure & 3.67 & 0.68 & 3.83 & 0.60 & 3.70 & 0.56 & 0.97 & 0.380 \\
Financial matters & 3.28 & 1.08 & 3.29 & 1.08 & 3.59 & 0.73 & 2.19 & 0.114 \\
Job description & 3.60 & 0.61 & 3.89 & 0.48 & 3.73 & 0.48 & 4.28 & 0.015 \\
Relationship & 3.86 & 0.64 & 4.02 & 0.47 & 3.70 & 0.60 & 3.50 & 0.032 \\
\hline
\end{tabular}

Table no 08 shows a comparison of emotional intelligence and job satisfaction on basis of teaching experience. Participants further were divided into three groups according to their teaching experience. There was a significant difference between the subject specialists having experience of 11-20 years and $<10$ years on job description $(\mathrm{F}=.014, \mathrm{p}=0.015)$. The participants having teaching experience 11-20 years $(\mathrm{M}=3.89$, $\mathrm{SD}=0.48)$ than the participants having experience $<10$ years $(\mathrm{M}=3.60, \mathrm{SD}=0.61)$. There was a significant difference between the subject specialists having experience 11-20 years and < 10 years on Relationship $(\mathrm{F}=.3 .50, \mathrm{p}=0.032)$ The participants having teaching experience $11-20$ years $(\mathrm{M}=4.02, \mathrm{SD}=0.47)$ were more satisfied with the relationship than the participants having experience $<10$ years $(\mathrm{M}=3.86, \mathrm{SD}=0.64)$. There was no significant difference in emotional intelligence and its factors and its two factors school infrastructure and financial matters.

Table no 09: Comparison of SS based on Academic Qualification on Emotional Intelligence and Job Satisfaction

\begin{tabular}{lllllllllll}
\hline & MA & \multicolumn{3}{c}{ M.Sc } & \multicolumn{3}{c}{ M, Phil } & PhD & \multicolumn{3}{c}{ ANOVA } \\
\hline & $M$ & $S D$ & $M$ & $S D$ & $M$ & $S D$ & $M$ & $S D$ & $F$ & $P$ \\
Emotional intelligence & 3.66 & 0.42 & 3.69 & 0.42 & 3.66 & 0.45 & 3.72 & 0.32 & 0.16 & 0.924 \\
Perceiving & 3.52 & 0.42 & 3.56 & 0.44 & 3.54 & 0.46 & 3.63 & 0.36 & 0.20 & 0.895 \\
Using & 3.70 & 0.56 & 3.80 & 0.55 & 3.77 & 0.64 & 3.96 & 0.32 & 0.72 & 0.543 \\
Understanding & 3.92 & 0.63 & 3.94 & 0.63 & 3.92 & 0.70 & 4.02 & 0.47 & 0.08 & 0.973 \\
Managing & 3.66 & 0.56 & 3.65 & 0.57 & 3.59 & 0.60 & 3.46 & 0.63 & .452 & .716 \\
Job satisfaction & 3.70 & 0.58 & 3.70 & 0.49 & 3.69 & 0.52 & 3.75 & 0.22 & 0.04 & 0.987 \\
School infrastructure & 3.71 & 0.65 & 3.71 & 0.62 & 3.67 & 0.70 & 3.83 & 0.25 & 0.18 & 0.912 \\
Financial matters & 3.44 & 0.91 & 3.33 & 0.97 & 3.34 & 1.17 & 3.44 & 1.04 & 0.20 & 0.895 \\
\hline
\end{tabular}




\begin{tabular}{lllllllllll}
\hline Job description & 3.66 & 0.62 & 3.70 & 0.55 & 3.66 & 0.61 & 3.70 & 0.24 & 0.09 & 0.967 \\
Relationship & 3.82 & 0.68 & 3.84 & 0.60 & 3.86 & 0.61 & 3.87 & 0.32 & 0.04 & 0.988 \\
\hline
\end{tabular}

Table no 09 shows a comparison of subject specialists on emotional intelligence and job satisfaction regarding their qualifications. There was no significant difference between emotional

Table no 10: Comparison of Unmarried and Married SS on Emotional Intelligence and Job Satisfaction.

\begin{tabular}{llllllll}
\hline & \multicolumn{2}{l}{ Unmarried } & \multicolumn{2}{l}{ Married } & \multicolumn{3}{l}{ Independent samples t-test } \\
\hline & $M$ & $S D$ & $M$ & $S D$ & $\mathrm{~T}$ & $\mathrm{df}$ & $\mathrm{P}$ \\
Emotional intelligence & 3.57 & 0.42 & 3.71 & 0.42 & -2.055 & 248 & 0.041 \\
Perceiving & 3.45 & 0.39 & 3.58 & 0.44 & -1.879 & 248 & 0.061 \\
Using & 3.70 & 0.64 & 3.79 & 0.54 & -1.115 & 248 & 0.266 \\
Understanding & 3.86 & 0.71 & 3.95 & 0.63 & -0.964 & 248 & 0.336 \\
Managing & 3.47 & 0.56 & 3.67 & 0.58 & -2.323 & 248 & 0.021 \\
Job satisfaction & 3.43 & 0.54 & 3.77 & 0.48 & -4.571 & 248 & $<.001$ \\
School infrastructure & 3.48 & 0.68 & 3.77 & 0.61 & -2.953 & 248 & 0.003 \\
Financial matters & 2.87 & 1.09 & 3.49 & 0.94 & -4.169 & 248 & $<.001$ \\
Job description & 3.33 & 0.62 & 3.78 & 0.52 & -5.391 & 248 & $<.001$ \\
Relationship & 3.74 & 0.73 & 3.87 & 0.58 & -1.441 & 248 & 0.151 \\
\hline
\end{tabular}

Independent samples t-test was conducted to compare Unmarried subject specialists and Married subject specialists on emotional intelligence and its factors, job satisfaction and its factors. There was a significant difference between unmarried and married subject specialists on emotional intelligence $(\mathrm{t}=-2.055, \mathrm{p}=0.041)$. The mean score of married $(M=3.71, S D=0.42)$ was more than unmarried subject specialists $(M=3,57, \quad S D=0.42)$. There was a significant difference between unmarried and married subject specialists on Managing $(\mathrm{t}=-2.323, \mathrm{p}=0.021)$. The mean score of married $(M=3,67, S D=0.58)$ was more than unmarried subject specialists $(M=3,47$, $S D=0.56$ ). There was a significant difference intelligence and job satisfaction of subject specialists having different qualifications such as MA, MSc, M.Phil. and Ph.D. 


\begin{tabular}{lcccccccccc}
\hline Perceiving & 3.56 & 0.43 & 3.53 & 0.39 & 3.62 & 0.44 & 3.49 & 0.51 & 3.42 & 0.018 \\
Using & 3.83 & 0.63 & 3.80 & 0.56 & 3.72 & 0.55 & 3.71 & 0.49 & 2.22 & 0.086 \\
Understanding & 3.98 & 0.68 & 3.92 & 0.68 & 4.02 & 0.57 & 3.80 & 0.61 & 1.76 & 0.156 \\
Managing & 3.66 & 0.61 & 3.62 & 0.53 & 3.72 & 0.58 & 3.52 & 0.58 & 1.19 & 0.313 \\
Job satisfaction & 3.63 & 0.61 & 3.68 & 0.49 & 3.87 & 0.42 & 3.67 & 0.43 & 1.11 & 0.344 \\
$\begin{array}{l}\text { School } \\
\text { infrastructure }\end{array}$ & 3.68 & 0.74 & 3.69 & 0.61 & 3.78 & 0.71 & 3.70 & 0.44 & 1.09 & 0.353 \\
$\begin{array}{l}\text { Financial } \\
\text { matters }\end{array}$ & 3.12 & 1.15 & 3.30 & 1.03 & 3.71 & 0.81 & 3.46 & 0.82 & 0.80 & 0.492 \\
Job description & 3.71 & 0.45 & 3.67 & 0.39 & 3.73 & 0.43 & 3.59 & 0.43 & 0.66 & 0.579 \\
Relationship & 3.56 & 0.43 & 3.53 & 0.39 & 3.62 & 0.44 & 3.49 & 0.51 & 0.28 & 0.838 \\
\hline
\end{tabular}

Table no 11 shows that there was a significant difference in emotional intelligence between subject specialists of age 40-50 years and subject specialists of $>50$ years $(\mathrm{F}=3.65, \mathrm{p}=0.013)$. It has been viewed that subject specialists having age 40-50 (M=3.73, $\mathrm{SD}=0.43)$ participants were more emotionally intelligent than of age., $>50$ ( $\mathrm{M}=3.59$. $\mathrm{SD}=0.43$ ) participants. Also, There was found a significant difference in perceiving between SS of age 40-50 years and subject specialists of $>50$ years $(\mathrm{F}=3.42, \quad \mathrm{p}=0.018) . \quad 40-50$ years age participants $(\mathrm{M}=3.62, \quad \mathrm{SD}=0.44)$ were more perceiving than $>50$ years of age participants. $(\mathrm{M}=3.49$. $\mathrm{SD}=0.51)$. There was no significant difference in using, understanding job satisfaction and its factors.

\section{FINDINGS:}

- A positive and strong correlation was found between emotional intelligence and job satisfaction $(\mathrm{r}=0.535, \mathrm{p}<.01)$ calculated through Pearson's coefficient.

- Female subject specialists were more satisfied with a financial matter, job description, and relationship than male. Female subject specialists were more perceiving, using, understanding and managing.

- The mean score of urban subject specialists was more than rural subject specialists.

- The mean score of married participants was more than unmarried participants.
- The subject specialists having teaching experience 11-20 Years were more satisfied than the subject specialists having experience $<10$ years and $>20$ years.

- Science group subject specialists were more emotionally intelligent than arts group subject specialists.

- The subject specialists having age 40-50 years were more emotionally intelligent than of age $<30,30-40$, and $>40$ years and also more satisfied than another age group.

\section{DISCUSSION:}

The present study was an effort to find an association between emotional intelligence and job satisfaction of subject specialists. The study has revealed a notable and encouraging relationship between both variables. The study further explained different demographic variables regarding emotional intelligence and job satisfaction. Different factors were elaborated to find out their relationship. The results of the study are in line with the results of the study done by Al-Saeeed et al. (2015) who also found a strong relationship between emotional intelligence with job satisfaction.

In this study job, satisfaction in the Pakistani context is strongly associated with emotional intelligence. Emotional intelligence is showing strong correlation with job satisfaction as is depicted in the study of Ealias \& George (2012) "There is a high positive relationship between emotional intelligence and job 
satisfaction which further shows that designation of the employee does not affect job satisfaction and emotional intelligence, however experience and marital status has significant effects on the two concepts". The results were in line with the present study which showed "a strong positive correlation between emotional intelligence of subject specialists and also showed significant effects on marital status, gender and experience." The study results by Yoke \& Panatik (2015) also revealed "a significant relationship between uses of emotion, regulation of emotion with job satisfaction while self-emotional appraisal was found to have no relationship with job satisfaction. The results are in line with the result of this study that emotional intelligence has a strong relationship with job satisfaction in subject specialists regarding perception, using, understanding, and managing emotions. Sharjeel (2010) found emotional intelligence and Job satisfaction have statistically remarkable contrast of college teachers in the context of organizational commitment and turnover intention. This study also predicted the same results in the Pakistani context at the school level.

The study by Masrek et al (2014) showed that "out of four clusters of emotional intelligence which are self-awareness, self-management, social awareness, and relationship management, only three turns out to be the significant predictors of job satisfaction" which is in line with the results of this study which showed a strong association of emotional intelligence and its factor i.e. perception, using, understanding and managing with job satisfaction in different groups.

The link between emotional intelligence and job satisfaction was determined by Mousavi et al (2012), of PET teachers, and a significant positive relationship between emotional intelligence and job satisfaction was found in the present study. Results are in line with Siddique et al. (2014) whose study revealed a significant association between two variables emotional intelligence and job satisfaction in Pakistani Higher Education institutions.

In the study by Lotfi-Goodarzi et al. (2012) notable link was investigated between teacher's emotional intelligence and job satisfaction, there were five major factors of job satisfaction i.e. nature of work, attitude towards supervisor and coworkers, promotion, and work condition but it was explored that there was no remarkable or strong relationship regarding salary and job satisfaction. The results of this study show a significant correlation between job satisfaction and emotional intelligence but found no significant association with financial matters. reported in their study that emotional intelligence is correlated with job satisfaction. This study is also reporting a positive significant correlation between both variables.

Masrek, and his colleagues (2014) pointed out that four factors of emotional intelligence i.e. self-vigilance, self-substances, and social awareness in relations, were significant predictors of Job Satisfaction of Malaysian Information Technology professionals. This study also reveals that managing is the best predictor of Job Satisfaction and also understanding and perceiving are the $2^{\text {nd }}$ and $3^{\text {rd }}$ best predictors respectively like the present study. The study results by Naz \& Liaquat (2015) found the impact of emotional intelligence on job satisfaction and psychological ownership among public and private employees showed a significant impact of emotional intelligence on job satisfaction. This study also stresses the emotional intelligence has a great impact on job satisfaction. It can be concluded that "teachers' job satisfaction may serve to influence their morale, motivation and general willingness to maximize their teaching potential" Northouse (2010).In developing countries like Pakistan, there is a need to increase the stress on emotional intelligence to increase their job satisfaction and vice versa. The excellence of teachers can be improved by enhancing their job satisfaction and emotional intelligence. Job satisfaction needs rewards or opportunities and keeps an eye on many workrelated factors such as the salary, working environment, infrastructure, timely promotions, job security behavior of supervisors and colleagues while to deal with such factors, a 
teacher needs to be emotionally intelligent. Emotional intelligence is a powerful aspect for influencing the job satisfaction of teachers.

\section{RECOMMENDATIONS:}

- The most important element in attaining the objectives of an organization is its workforce and success depends on its human resources. The teachers play a major role in the growth of student's personality, expertise, skills, and understanding, necessary for their whole life action. For achieving these goals, the mandatory conditions must be provided to the teachers so that they perform their duties in an appealing environment and with pleasure that is with job satisfaction.

- Job satisfaction is linked with handsome salary, the nature of work, up-gradation, leadership command, and relation with colleagues, job security, and building structure, the physical condition of the job, personality factor, personal appearance, and fairness which should be properly arranged and provided to teachers.

- Teachers with fewer workplace pressures, enjoy a higher level of job satisfaction. This stress can be minimized by satisfying their basic needs and by providing them training for becoming emotionally intelligent like developed countries to make them more effective and efficient. It is need of time to strengthen the basic needs of teachers to make them more efficient and more satisfied so they may be more productive for the society.

- Teachers also need psychological support for enjoying their workplace duties, responsibilities and for becoming emotionally intelligent. For this purpose, workshops conducted by psychologists can be arranged for them, and follow up practices can also be pursued.
[1] Afolabi, O. A., Ogunmwonyi, E., \& Okediji, A. (2009). Influence of emotional intelligence and need for achievement on interpersonal relations and academic achievement of undergraduates. Educational research quarterly, 33(2), 15.

[2] Aftab, L.(2015). The relation of leadership style and emotional intelligence and job satisfaction of lifeguard staff of the country. International Journal of Engineering and Applied Sciences, 2(10), 257807.

[3] Akomolafe, M. J., \& Ogunmakin, A. O. (2014). Job satisfaction among secondary school teachers: Emotional intelligence, occupational stress and self-efficacy as predictors. Journal of Educational and Social Research, 4(3), 487-487.

[4] Al-Saeed, H. A., Al-Hamami, M. N., Hashim, T. M., \& Songip, R. A. (2015). The Effects of Emotional Intelligence on Job Satisfaction. Information and Knowledge Management, 5(6), 98-102.

[5] Armstrong, M. (2006). A handbook of human resource management practice. Kogan Page Publishers.

[6] Aykan, E. (2014).Relationships between emotional competence and task-contextual performance of employees. Problems of Management in the 21st Century, 9(1), 8.

[7] Aykan, E., \& Aksoylu, S. (2015). Mediating role of job satisfaction over the impacts of emotional competences of employees on perceived service quality: A research on accounting professionals. Erciyes Üniversitesi İktisadi ve Idari Bilimler Fakültesi Dergisi, (46), 101-117.

[8] Aziri, B. (2011). Job Satisfaction: A Literature Review. Management Research \& Practice, 3(4).

[9] Bar-On, R. E., \& Parker, J. D. (2000). The handbook of emotional intelligence: theory, development, assessment, and 
application at home, school, and in the workplace. Jossey-Bass.

[10] Biswas, R.A. (2106).Emotional intelligence and job satisfaction of teachers: An analysis. International Journal of Humanities and social Studies.4(5).

[11] Cobb, B. (2004). Assessing job satisfaction and emotional intelligence in public school teachers.

[12] Ealias, A., \& George, J. (2012). Emotional intelligence and job satisfaction: A correlational study. Research journal of commerce and behavioral science, 1(4).

[13] El Badawy, T. A., \& Magdy, M. M. (2015). Assessing the impact of emotional intelligence on job satisfaction: An empirical study on faculty members with respect to gender and age. International Business Research, 8(3), 67.

[14] El Badawy, T. A., \& Magdy, M. M. (2015). Assessing the impact of emotional intelligence on job satisfaction: An empirical study on faculty members with respect to gender and age. International Business Research, 8(3), 67.

[15] Emmerling, R. J., \& Goleman, D. (2003). Emotional intelligence: Issues and common misunderstandings. Issues and Recent Developments in Emotional Intelligence, 1(1), 1-32.

[16] Fakiruddin, N. A. S. (2011). The impact of employees' emotional intelligent on job satisfaction: the experience of employees at Vista Point Sdn Bhd (Master's thesis, Kuala Lumpur: International Islamic University Malaysia, 2011).

[17] Gay, L. R. (1996). Educational Research: Competencies for Analysis and Application. New Jersey: Merrill.

[18] Gay, P. D., \& Salaman, G. (1992). The cult [ure] of the customer. Journal of management studies, 29(5), 615-633.

[19] George, J. (2014). Emotional Intelligence and Job Satisfaction: A Correlational study. Research journal of commerce and behavioral sciences, 1(4), 37-42.

[20] Hayat, I., Bibi, T., \& Ambreen, M. (2016). Gender Influence on Emotional Intelligence and Professional Development among Secondary School Teachers. Science International, 28(1).

[21] Hekmatzadeh, M. H., Khojasteh, L., \& Shokrpour, N. (2016). Are Emotionally Intelligent EFL Teachers More Satisfied Professionally?. International Journal of Applied Linguistics and English Literature, 5(2), 97-107.

[22] Kaliski, B. S. (2007). Encyclopedia of business and finance (2nd Ed.). Detroit: Thompson Publishers.

[23] Kappagoda, U. W. M. R. (2015). The relationship between principals' emotional intelligence and teachers' job satisfaction: A case of national schools in Sri Lanka. In International Conference on Business \& Information.

[24] Kassim, S. I., Bambale, A. J., \& Jakada, B. A. (2016). Emotional Intelligence and Job Satisfaction among Lecturers of Universities in Kano State: Empirical Evidence. Journal of Education and Practice, 7(10), 53-59.

[25] Kosteas, V. D. (2011). Job satisfaction and promotions. Industrial Relations: A Journal of Economy and Society, 50(1), 174-194.

[26] Kportufe, J. (2014). Assessing the impact of emotional intelligence on employee customer service delivery: A case study of banking sector in Ghana (Doctoral dissertation).

[27] Lotfi-Goodarzi, F., \& YahyazadehJeloudar, S. (2012). Teachers' Emotional Intelligence and Its Relationship with Job Satisfaction. Advances in Education, 1(1), 4-8.

[28] Masrek, N. M., Osman, F. A. M., Khamis, Y., \& Paiman, J. M. (2014). The Relationship Between Emotional Intelligence and Job Satisfaction: The Case 
of Malaysian Information Technology Professionals. International Journal of Multidisciplinary and Current Research, 2(4), 1106-1111.

[29] Mayer, J. D., \& Geher, G. (1996). Emotional intelligence and the identification of emotion. Intelligence, 22(2), 89-113.

[30] Mousavi, S. H., Yarmohammadi, S., Nosrat, A. B., \& Tarasi, Z. (2012). The relationship between emotional intelligence and job satisfaction of physical education teachers. Annals of Biological Research, 3(2), 780-788.

[31] Mullins, L. J. (2007). , J. D., \& Geher, G. (1996). Emotional Intelligence and the Identification of Emotion. Intelligence, 22(2), 89-113.

[32] Mullins, L. J. (2007). , J. D., \& Geher, G. (1996). Emotional Intelligence and the Identification

Emotion. Intelligence, 22(2), 89-113.

[33] Naz, S., \& Liaquat, S. (2015). Impact of Emotional Intelligence on job Satisfaction and Psychological Ownership among Public and Private Employees: A Case Study of Multan City. Pakistan Journal of Social Sciences (PJSS), 35(2).

[34] Northhouse, P.G.(2010).Leadership: Theory and Practice.NY:Sage.

[35] Orhan, N., \& Dincer, H. (2012). The impacts of Emotional intelligence competency on job satisfaction in the service sector: An application on the Turkish banking sector. Asian Economic and Financial Review, 2(5), 617.

[36] Orodho, J. A. (2014). Policies on free primary and secondary education in East Africa: Are Kenya and Tanzania on course to attain Education for All (EFA) Goals by 2015. International Organization of Scientific Research (IOSR) Journal of Humanities and Social Sciences (IOSRJHSS), 19, 11-20.

[37] Salim, S. S. S., Nasir, R., Arip, M. A. S. M., \& Mustafa, M. B. (2012). The role of emotional intelligence on job satisfaction among school teachers. Social Sciences, 7(1), 125-129.

[38] Schutte, N. (1998). Schutte self-report emotional intelligence test (sseit). Preuzeto, 8, 2017.

[39] Sharjeel, M. S. (2010). Emotional intelligence as a predictor of organizational Commitment among college teachers. Unpublished doctoral dissertation. University of Education Township, Lahore, Pakistan.

[40] Shooshtarian, Z. (2013). The effect of labor's emotional intelligence on their job satisfaction, job performance and commitment. Iranian Journal of Management Studies, 6(1), 27-43.

[41] Siddique, S., Riaz, F., Siddique, A., Riaz, A., Nawaz, Y., \& Shehzadi, S. (2014). Role of Emotional Intelligence on Job Satisfaction in University Teacher. Academic Journal of Interdisciplinary Studies, 3(6), 327-327.

[42] Statt, D. A. (2004). The Routledge Dictionary of Business Management. Routledge.Rome-Italy.3 (6).327-332.

[43] Yoke, L. B., \& Panatik, S. A. (2015). Emotional intelligence and job performance. Asian Social Science Canadian Center of Science and Education.11(13) 806-812. 